EESTI NSV TEADUSTE AKADEEMIA TOIMETISED 1954. III kd., nr. 2 ИЗВЕСТИЯ АКАДЕМИИ НАУК ЭСТОНСКОИ ССР 1954. Том III, № 2

\title{
SUVINISU SAAGISTRUKTUUR OLENEVALT SORTIDE BIOLOOGILISTEST ERIOMADUSTEST JA KASVUTINGIMUSTEST
}

\author{
O. PRIILINN, \\ põllumajandusteaduste kandidaat
}

NLKP Keskkomitee septembri- ja veebruari-märtsipleenum otsustasid pidada vajalikuks igati arendada teraviljamajandust ning eriti kốige väärtuslikuma toiduteravilja - tali- ja suvinisu - tootmist. Veebruari-märtsipleenumi otsuses on ette nähtud teravilja tootmise tunduv suurendamine uudis- ja jäätmaade ülesharimise teel. Samas juhitakse tähelepanu vajadusele märksa tõsta teraviljakultuuride saagikust, mis on olnud ja jääb teravilja tootmise suurendamise peamiseks abinõuks.

Partei ja valitsuse poolt seatud ülesannete edukas täitmine saagikuse tõstmise alal nõuab kõrge saagi kujunemise teadlikku juhtimist. Sotsialistliku põllumajanduse arenemise tingimustes ei või agrotehnika küsimusi lahendada lihtsalt antud kultuuri suhtes tervikuna, arvestamata iga kultuuri eri sortide bioloogilisi iseärasusi. Ei tohi unustada seda, et saagikuse tõstmise reservide täielikum ärakasutamine ei ole võimalik juhindudes ainult üldistest empiirilistest agrotehnilistest reeglitest ja neid mehaaniliselt rakendades erinevates tingimustes, arvestamata sortide vajaduste erinevusi ja kasvutingimusi. Mida sügavamalt tungime taimede arenemise seaduspärasustesse ja mida rohkem avastame eri sortides peituvaid reserve, seda paremaid tulemusi saakide tõstmise alal saavutame taimede kasvu ja arenemise suunava juhtimisega.

Alljärgnevalt käsitletakse uurimust, mille ülesandeks oli selgitada Eesti NSV-s suurte suvinisusaakide kasvatamise bioloogilisi aluseid ja taimede bioloogiliste omaduste arvestamise alusel teaduslikult põhjendada sordiagrotehnika rakendamise vajadust. Tuuakse ära põhilisemad tulemused suvinisu saagikuse tõstmise küsimuste uurimise alalt seoses taime nende organite ja osade kujunemise suunava mõjutamisega, milledest moodustub saak. Töös iseloomustatakse Eesti NSV-s rajoonitud ja Jõgeva Riiklikus Sordiaretusjaamas aretatud perspektiivsete suvinisusortide saagi kujunemist erinevates kasvu- ja arenemistingimustes, lähtudes taimede stadiaalse arenemise teooriast. Eksperimentaalsed uurimised teostati Jõgeva Riiklikus Sordiaretusjaamas ja Eesti NSV Teaduste Akadeemia Taimekasvatuse Instituudi Tallinna Eksperimentaalbaasis aastail 1951-1953. Töötati läbi ka Eesti NSV riiklike sordivõrdluskatsepunktide 1950. ja 1951.' aasta aruanded. 


\section{Uurimise alused}

Teraviljakultuuride saagi suuruse pinnaühikult määravad põhiliselt järgmised näitajad: 1) taimede arv pinnaühikul, 2) produktiivne vôrsumine, 3) pähikute arv peas, 4) terade arv pähikus, 5) 1000 tera kaal.

Neid näitajaid nimetatakse saagistruktuuri elementideks ehk saagielementideks $(8,3,11,9$.$) .$

Saagielementide kujunemise uurimise aluseks on akadeemik T. D. Lõssenko poolt välja töötatud taimede stadiaalse arenemise teooria, sest ,,arenemisjärkude alusel kujunevad taime osad ja organid, tema mitmesugused tunnused ja omadused. Mõned neist on ainult ühe teatava arenemisjärgu läbimise tulemus, teised on aga omased mitmele või koguni kõikidele arenemisjärkudele" $\left({ }^{2}\right)$.

Saagielementide kujunemine on lahutamatult seotud taimede kasvu- ja arenemistingimustega. Produktiivsete kõrte arv pinnaühiku kohta, pähikute arv peas, terade arv pähikus, 1000 tera kaal jne. on kasvu- ja arenemisprotsesside kulgemise tulemus taimede arenemise järkjärgulistes staadiumides. Suurte saakide saamiseks on vajalik teada saagielementide arenemiseks vajalikke tingimusi, et teadlikult mõjutada nende kujunemist meile soovitavas suunas.

Nõukogude teadlaste poolt taimede stadiaalse arenemise teooria alusel teostatud uurimised on näidanud, et teraviljade ja nende hulgas ka suvinisu pea algme diferentseerumine toimub valgusestaadiumis $(4,10,5,6,7$ ). Pea arenemine on seotud stadiaalsete protsessidega taimes. Jarovisatsioonistaadiumi täieliku läbimise ja valgusestaadiumi alguse morfoloogiliseks näitajaks loevad paljud autorid kasvukuhiku väljavenimist ja diferentseerumist, kuid on ka teisi arvamusi. A. K. Fjodorovi $\left({ }^{12}\right)$ andmeil võib arenemise valgusestaadium alata ka enne kasvukuhiku diferentseerumist. Kirjanduses avaldatud erinevate katsetulemuste ja uurimuste põhjal võib järeldada, et valgusestaadiumi algust ja lõppu ei ole alati võimalik siduda kindlate morfoloogiliste muutustega kasvukuhikus. Valgusestaadiumi kestus kõigub suurtes piirides, olenevalt sordist ja kasvutingimustest.

Taimede morfogeneesi ja saagielementide kujunemise uurimise tähtsus seisab selles, et ta annab meile taimes toimuvatest protsessidest ja nende kulgemise intensiivsusest erinevatel arenemisstaadiumidel ja välistingimustes ettekujutuse, mida saab kasutada suurte saakide agrotehnika teaduslikuks pōhjendamiseks ning efektiivsete agrotehniliste võtete väljatöötamiseks.

\section{Saagistruktuuri võrdlev uurimine sordivõrdluskatsetes}

Suvinisusortide bioloogiliste omaduste iseloomustamiseks ja Eesti NSV-s suurte saakide saamise bioloogiliste aluste selgitamiseks viidi Jõgeva Riiklikus Sordiaretusjaamas 1951. ja 1952. aastal teostatud sordivõrdluskatsete juures autori poolt läbi saagistruktuuri uurimine. Katsed, mis teostati kõrgel agrofoonil, rajati põldheina järel, erinevatel väetisfoonidel. Katsed rajati neljas korduses katselappidele pindalaga $50 \mathrm{~m}^{2}$. Külv teostati käsiplaneediga, reavahega $12,5 \mathrm{~cm}$, külvinormiga 650 idanevat tera ühele ruutmeetrile.

Pärast orase täielikku tärkamist eraldati igalt korduselt kolm proovilappi, igaüks pindalaga $1 / 6 \mathrm{~m}^{2}$. Taimede arv proovilappidel loeti pärast täielikku tärkamist ja enne koristamist. Võetud proovivihke kasutati saagistruktuuri analüüsimisel. Pea produktiivsus ja teised tunnused määrati 100 pea analüüsi alusel.

1951. aastal korraldatud katsetel anti katsepõllule kevadel enne kulti- 
veerimist 4,5 ts granuleeritud superfosfaati, 1,7 ts kaalisoola ja 1,1 ts ammooniumsalpeetrit hektari kohta.

1951. aastal võeti uurimise alla 7 sorti: vabariigi rajoonitud sordid „Diamant” ja „Kauka” ning Jōgeva Riiklikus Sordiaretusjaamas areiatud perspektiivsed sordid „0888”, „01926”, „01302”, „01926.4” ja „01923.11”. Peale nende uuriti ka sortidevahelisest ristamisest tuultolmlemise teel saadud ,Diamandi” ja „Kauka” hübriidi saagistruktuuri kujunemist.

1952. aastal uuriti saagistruktuuri kahel erineval väetisfoonil — tavalisel ja kõrgemal.

Tavalisele foonile anti eelmise aasta sügisel 2,0 ts superfosfaati ja 1,0 ts kloorkaaliumi hektari kohta ning külviaasta kevadel enne kultiveerimist täiendavalt 1,0 ts ammooniumsulfaati ja 1,5 ts orgaaanilis-mineraalseid graanuleid $(0,75$ ts superfosfaati ja 0,75 ts hästilagunenud turvast). Seega sai iga hektar 2,75 ts superfosfaati, 1,0 ts kloorkaaliumi, 1,0 ts väävelhaput ammooniumi ja 0,75 ts turvast.

Körgemale foonile anti kevadel enne kultiveerimist 3,0 ts superfosfaati, 1,5 ts kloorkaaliumi, 1,5 ts väävelhaput ammooniumi ja 2,25 ts orgaanilismineraalseid graanuleid hektari kohta.

1951. aasta vegetatsiooniperioodi ilmastikuolud erinesid tunduvalt ilmastikuoludest 1952. aasta vegetatsiooniperioodil. 1951. aastal oli ajavahemikul tärkamisest kuni võrsumiseni tavalisest madalam temperatuur, võrsumisest kuni kōrdumiseni aga soe ja kuiv ilm. Loomise-eelsel perioodil ja loomise ajal valitses soodne veerežiim. Tera valmimise ja küpsemise perioodil domineerisid kõrge temperatuur ja põuatingimused. 1952. aasta vegetatsiooniperioodil oli temperatuur madal ja sademeid palju, eriti suve teisel poolel. Ohu ja mulla suur niiskus pikendas suvinisu valmimist ja küpsemist.

1951. aasta katses saadi körgeid saake, mis ulatusid $34,2-45,4$ tsentnerini hektari kohta, kusjuures kõige madalama saagi andis „,Diamant”.

Kõige kõrgema terasaagi andis perspektiivne sort „Jõgeva 01926”.

Teised perspektiivsed sordid jäid nii saagilt kui ka muude näitajate poolest „Jōgeva 01926-st” maha. Sortide üksikasjaline iseloomustus on ära toodud tabelis 1 .

Saagistruktuuri analüüsi andmeist nähtub, et eri sordid, vastavalt nende bioloogilistele ja füsioloogilistele omadustele, annavad ühtedes ja samades tingimustes erineva struktuuriga saagi.

1951. aastal uuriti ka hübriidseemnete saagistruktuuri kujunemist.

On teada, et vaba sortidevahelise ristamise tulemusena rikastub taimede pärilikkus ja tõuseb elujõulisus, mille tulemusena suureneb ka saagikus. Senini on aga vähe uuritud hübriidseemnete saagi kujunemist ja pole selgitatud, missuguste saagielementide intensiivsema väljaarenemise tõttu saadakse hübriidseemne enamsaak emasortidega võrreldes.

Hübriidseemnete saamiseks külvati Jõgeval 1950. aastal ridadena tolmutajate segusse emasordid „Diamant” ja „Kauka”. Isasortidena külvati mõlema sordi tolmutamiseks ühed ja samad sordid, nimelt „Jõgeva 0888”, „Jõgeva 01926”, „Moskovka 48”, „,Flora 5”, „,Diamant” ja „,Kauka”. Kohe pärast loomist teostati emasortide kastreerimine. Sellega loodi tingimused valikviljastumiseks.

Uurimine näitas, et taimede hübriidne loomus ja suurem elujõulisus põhjustasid peaaegu kõikide saagielementide intensiivsema väljaarenemise ja seega saagi tõusu. „Diamandi” ja „Kauka” hübriidseeme kindlustas taimede suurema seisutiheduse seemnete parema tärkavuse tõttu, andes samuti pea suurema produktiivsuse emasortidega võrreldes. Pea produktiivsus kasvas „Diamandi” hübriidil terade arvu ja nende kaalu suurenemise, „Kauka” hübriidil aga terade kaalu suurenemise tulemusena.

1952. aasta katsetes oli terasaak tavalisel foonil $18,1-19,9$ ts ja kõrge- 
Suvinisusortide saagistruktuur 1951. aastal

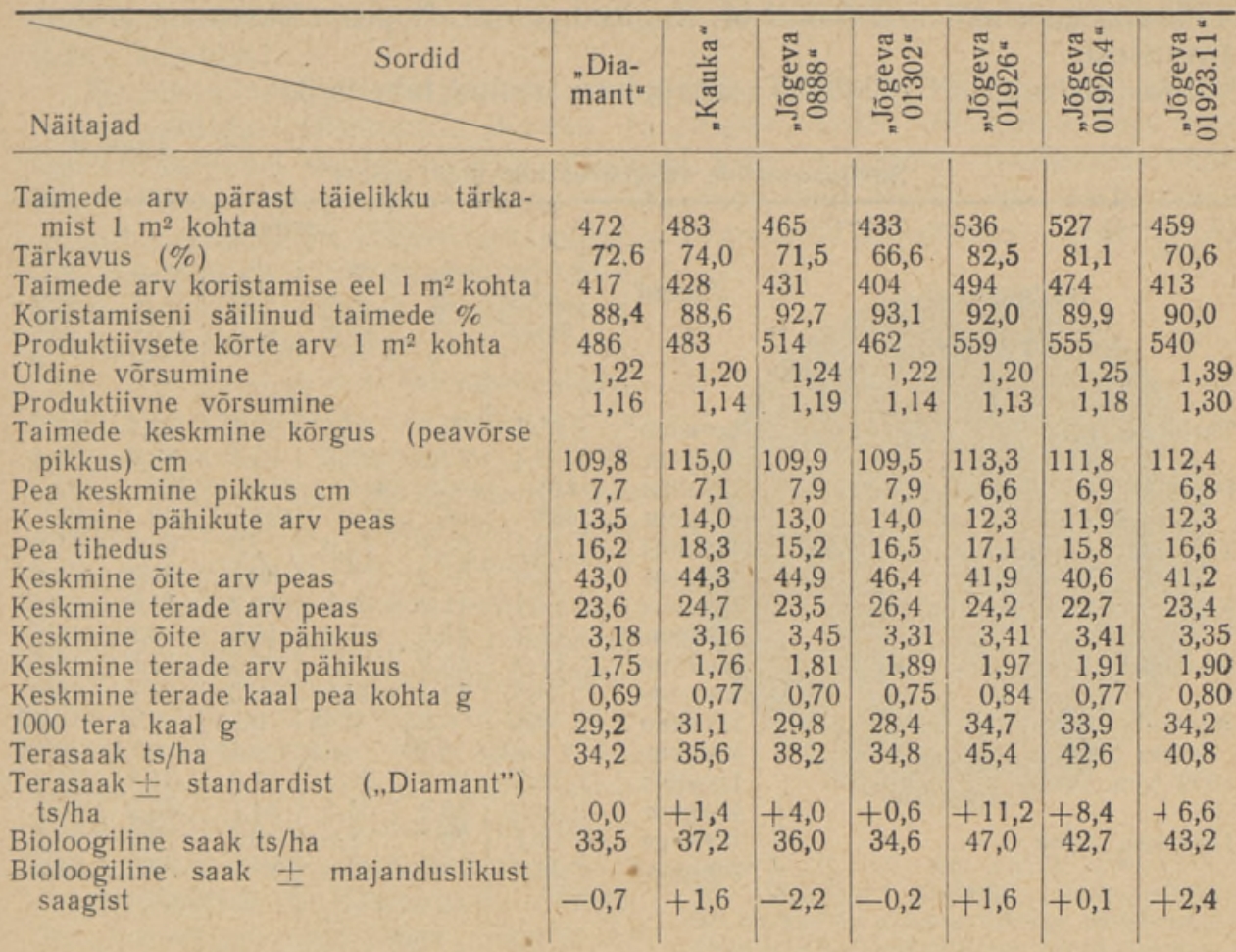

Tabel 2

„Diamandi” ja „Kauka” hübriidi saagistruktuur emasortidega võrreldes

\begin{tabular}{|c|c|c|c|c|}
\hline Näitajad & $\begin{array}{c}\text { ¿Dia- } \\
\text { mandi } \\
\text { hübriid }\end{array}$ & $\begin{array}{l}{ }_{n} \mathrm{Dia}- \\
\text { mant" }\end{array}$ & $\begin{array}{l}\text { "Kauka" } \\
\text { hübriid }\end{array}$ & ${ }_{\text {„Kauka }}$ \\
\hline $\begin{array}{l}\text { Tärkavus }(\%) \\
\text { Produktiivsete kõrte arv } 1 \mathrm{~m}^{2} \text { kohta } \\
\text { Taimede keskmine kõrgus (peavõrse pik- } \\
\quad \text { kus) cm } \\
\text { Pea keskmine pikkus cm } \\
\text { Keskmine pähikute arv peas } \\
\text { Keskmine terade arv peas } \\
\text { Keskmine terade kaal pea kohta } \mathrm{g} \\
1000 \text { tera kaal g } \\
\text { Terasaak ts/ha }\end{array}$ & $\begin{array}{c}83,2 \\
527 \\
113,5 \\
7,9 \\
13,8 \\
24,9 \\
0,76 \\
30,5 \\
36,6\end{array}$ & $\begin{array}{c}72,6 \\
486 \\
109,8 \\
7,7 \\
13,5 \\
23,6 \\
0,69 \\
29,2 \\
34,2\end{array}$ & $\begin{array}{c}82,5 \\
515 \\
114,2 \\
7,3 \\
13,8 \\
24,2 \\
0,79 \\
32,6 \\
38,9\end{array}$ & $\begin{array}{c}74,0 \\
483 \\
115,0 \\
7,1 \\
14,0 \\
24,7 \\
0,77 \\
31,1 \\
35,6\end{array}$ \\
\hline
\end{tabular}

mal foonil $28,0-30,2$ ts hektari kohta. Järehikult saadi kõrgemal foonil keskmiselt 10 ts/ha võrra suurem saak kui tavalisel foonil. Mổlemal foonil ületasid kõik sordid „Diamandi”, kuid enamsaak osutus 1951. aastaga võrreldes väga väikeseks. Séda saab osaliselt seletada sellega, et „Diamant” näib olevat teistest sortidest niiskusenõudlikum ja võib ka paremini taluda liigniiskust, mis esines 1952. aastal.

Saagistruktuuri analüüsi andmed näitavad, et kõrgemal foonil arenesid paremini välja kõik saagielemendid, kuid erineval määral, olenevalt sortide 
bioloogilistest omadustest. Kõrgemal agrofoonil oli kõikide sortide kõrte seis tihedam ja pea produktiivsus suurem kui tavalisel foonil. „Diamandi” väiksem saak mōlemal foonil oli tingitud peamiselt pea väiksemast produktiivsusest.

Saagistruktuuri põhilised näitajad on toodud tabelis 3 .

Tabel 3

Suvinisusortide saagistruktuur 1952 . aastal

\begin{tabular}{|c|c|c|c|c|c|c|c|}
\hline \multirow[b]{2}{*}{ Näitajad } & \multirow[b]{2}{*}{ Foonid } & \multicolumn{6}{|c|}{ Sordid } \\
\hline & & $\begin{array}{l}\text { Dia- } \\
\text { mant" }\end{array}$ & 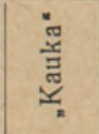 & 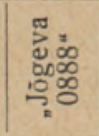 & 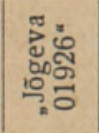 & 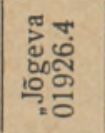 & 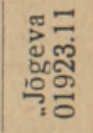 \\
\hline $\begin{array}{l}\text { Tärkavus (\%) } \\
\text { Produktiivsete kōrte arv koris- } \\
\text { tamisel } 1 \mathrm{~m}^{2} \text { kohta } \\
\text { Taimede keskmine kõrgus (pea- } \\
\text { võrse pikkus) cm } \\
\text { Keskmine pähikute arv peas } \\
\text { Keskmine terade arv peas } \\
\text { Keskmine terade kaal pea } \\
\text { kohta g k } \\
1000 \text { tera kaal } \\
\text { Terasaak ts/ha }\end{array}$ & $\begin{array}{l}\text { tavaline } \\
\text { kõrgem } \\
\text { tavaline } \\
\text { kõrgem } \\
\text { tavaline } \\
\text { kõrgem } \\
\text { tavaline } \\
\text { kõrgem } \\
\text { tavaline } \\
\text { kõrgem } \\
\text { tavaline } \\
\text { kõrgem } \\
\text { tavaline } \\
\text { kõrgem } \\
\text { tavaline } \\
\text { kõrgem }\end{array}$ & \begin{tabular}{|c|}
85,1 \\
89,4 \\
418 \\
488 \\
73,1 \\
73,4 \\
11,1 \\
11,2 \\
17,9 \\
18,9 \\
0,51 \\
0,63 \\
28,5 \\
33,3 \\
18,1 \\
28,0
\end{tabular} & $\begin{array}{c}79,2 \\
82,6 \\
403 \\
456 \\
64,8 \\
67,2 \\
11,4 \\
11,7 \\
16,8 \\
19,5 \\
0,55 \\
0,70 \\
32,7 \\
35,9 \\
19,7 \\
29,4\end{array}$ & $\begin{array}{l}80,5 \\
80,5 \\
414 \\
471 \\
70,0 \\
77,2 \\
10,1 \\
11,4 \\
16,9 \\
20,3 \\
0,48 \\
0,64 \\
28,4 \\
31,5 \\
18,3 \\
28,9\end{array}$ & $\begin{array}{l}82,5 \\
86,5 \\
410 \\
491 \\
72,8 \\
80,0 \\
10,3 \\
10,9 \\
17,4 \\
19,3 \\
0,54 \\
0,67 \\
31,0 \\
34,7 \\
19,8 \\
29,9\end{array}$ & $\begin{array}{c}72,2 \\
83,2 \\
386 \\
468 \\
66,2 \\
60,2 \\
10,5 \\
10,9 \\
17,9 \\
19,2 \\
0,57 \\
0,71 \\
31,8 \\
36,9 \\
19,2 \\
30,2\end{array}$ & $\begin{array}{c}86,0 \\
85,4 \\
432 \\
481 \\
65,8 \\
71,5 \\
10,4 \\
10,5 \\
16,7 \\
18,0 \\
0,53 \\
0,65 \\
31,7 \\
36,1 \\
19,9 \\
28,9\end{array}$ \\
\hline
\end{tabular}

\section{Külviaja mõju taimede arenemisele ja saagistruktuuri kujunemisele}

Suvinisu varase külvamise saakitõstev mõju on Eesti NSV-s tõestatud rohkearvuliste katsetega (E. Haller) ja praktiliste kogemustega, kuid pole uuritud erinevate külviaegade mõju taime nende organite ja osade arene-

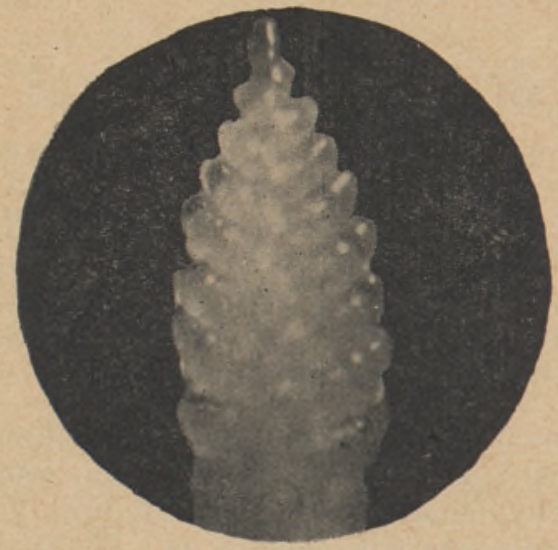

Joon. 1. „Kauka” pea algme arenemine 15. juuniks taimedel esimesest külviajast 25. päeval pärast tärkamist. Diferentseerumine pähikuteks on lõppenud.

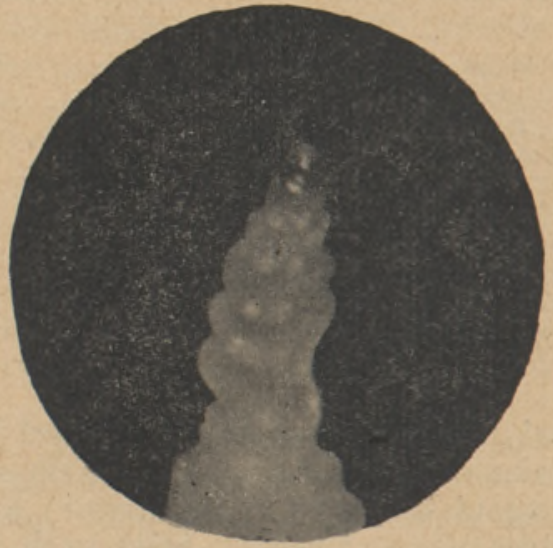

Joon. 2. „Kauka” pea algme arenemine 15. juuniks taimedel teisest külviajast 16. päeval pärast tärkamist. Diferentseerumine pähikuteks kestab. 
misele, millest moodustub saak. Seega ei ole varase külvi mõjule antud bioloogilist pöhjendust taimede stadiaalse arenemise ja taimede produktiivsuse kujunemise seisukohalt. Samuti ei ole andmeid sortide reageerimise kohta külviajale.

Nende küsimuste valgustamiseks rajati 1952. ja 1953. aastal katsed kolme sordiga: „Diamant”, „Kauka” ja „Jõgeva 01926”. Esimene külv teostati varakevadel esimesel külvivõimalusel, teine ja kolmas 10-päevaste vahedega. Pärast teise lehe ilmumist kuni loomiseni uuriti iga $3-5$ päeva tagant kasvukuhiku diferentseerumist ja pea algme kujunemist (joon. 1-3).

Vaatlused ja uurimised näitasid, et olenevalt erinevatest temperatuuri, päeva pikkuse ja veerežiimi tingimustest, mis luuakse eri külviaegadega, toimub ka taimede kasv, arenemine ja saagielementide kujunemine. Tingimustest valgusestaadiumis oleneb pea algme kasvu ja arenemise tempo ning pea produktiivsus. Eesti NSV klimaatilistes tingimustes esineb hiliskevadeti sageli põuda, mis põhjustab hiliste külvide pea algme kiiret arenemist, kuid kidura kasvu tõttu pea produktiivsuse langust. Varase külvi korral langeb suvinisul valgusestaadiumi läbimine ja pea algme arenemine pea produktiivsuse kujunemise suhtes soodsamatesse tingimustesse, võrreldes hilisemate külvidega, Kasvu ja arenemist soodustab madalam temperatuur, ühtlasem veerežiim ja lühem

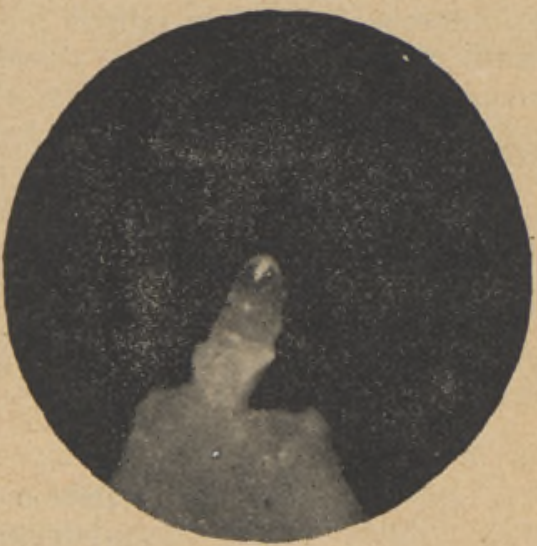

Joon. 3. „Kauka” pea algme arenemine 15. juuniks taimedel kolmandast külviajast 9. päeval pärast tärkamist. Valgusestaadiumi algus; algab kasvukuhiku väljavenimine ja pähikuteks diferentseerumine. päev.

Saagistruktuuri analüüsi andmed näitasid, et kõrgem saak esimesel külviajal hilisemate külvidega võrreldes kindlustatakse produktiivsete kõrte tihedama seisu ja terade suurema kaalu tõttu. Külvi hilinemisel langes tunduvalt seemnete tärkavus ja taimede vōrsumine. Samal ajal suurenes mitteproduktiivsete kõrte arv pinnaühiku kohta. Külvi hilinemisel langes „Jõgeva 01926” terasaak suhteliselt rohkem kui „Diamandi” ja „Kauka” terasaak.

\section{Külvitiheduse mõju saagistruktuuri kujunemisele}

Olenevalt sortide agrobioloogilistest iseärasustest ja kasvutingimustest on kõrgete saakide kindlustamiseks vajalik koos teiste agrotehniliste võtetega diferentseerida ka külvinorme. Eesti NSV-s on veel vähe uuritud külvinormide mõju suvinisusortide saagi kujunemisele. Seoses maaviljeluse heinaväljasüsteemi juurutamisega ja põllunduskultuuri üldise tõusuga suureneb vajadus uurida külvitiheduse mõju saagi kujunemisele erinevates kasvutingimustes.

Külvitiheduse mõju uurimiseks erinevatel agrofoonidel „Diamandi”, „Kauka” ja „Jõgeva 01926” saagistruktuuri kujunemisele rajati katsed madalal ja kõrgemal agrofoonil. Külvati 500, 600, 700 ja 800 idanevat tera $1 \mathrm{~m}^{2}$ kohta.

Uurimine näitas, et sordile ja kasvutingimustele vastav optimaalne külvinorm, mis võimaldab sordiomaduste täielikumat ärakasutamist saagikuse tõstmiseks, on sordiagrotehnika kompleksis üheks tähtsamaks teguriks. 
Katsetes suurenes madalal agrofoonil külvinormi tõstmisega kõikide sortide terasaak. Kõrgemal foonil suurenes külvinormi tõstmisega tunduvalt „Kauka” terasaak, kuid ei tõusnud „Diamandi” ja „Jõgeva 01926” saak. Sortide niisuguse erinevuse üheks põhjuseks võib lugeda „Kauka” nõrka võrsumist. Madalama külvinormi rakendamisel andis „Kauka” liiga hõreda kõrteseisu. Kaaluliselt ühesuguse külvinormi kasutamisel on pealegi „Kauka” terade arv pinnaühiku kohta tunduvalt kõrgema 1000 tera kaalu tõttu väiksem kui „Diamandil”. Tootmispraktikas aga sageli ei arvestata külvinormide kasutamisel neid sordi iseärasusi.

Kui külvinormi suurendamisega kõrte arv pinnaühikul tõusis, siis pea keskmine produktiivsus langes pidevalt. Kõrteseisu tiheduse suurendamisel teatud piirini (optimumini) tõuseb terasaak vaatamata pea produktiivsuse samaaegsele langemisele. Kõrteseisu tiheduse edasisel suurendamisel aga terasaak enam ei tõuse, vaid hakkab langema pea produktiivsuse järsu vähenemise tõttu. „Kauka” pea produktiivsus langes külvinormi suurendamisel tunduvalt vähem kui „Diamandi” ja „,Jõgeva 01926” pea produktiivsus. Arvestades katsete tulemusi ja tootmispraktika kogemusi, on vajalik välja selgitada külvinormide suurendamises peituvad saagikuse tõstmise reservid, eriti „Kauka” kohta. Ulesanne seisab selles, et sordiomadusi ja kasvutingimusi arvestades kindlaks teha külvinormid, mis kindlustaksid kõige suuremad saagid.

\section{Mineraalväetiste mõju taimede arenemisele ja saagistruktuuri kujunemisele}

Sortide produktiivsusomaduste avaldumine oleneb suurel määral taimede toitumise tingimustest. Toiteelementide mõju suvinisusortide arenemisele ja sáagistruktuuri kujunemisele uuriti pōld- ja vegetatsioonikatsetes.

Põldkatsed rajati järgmistes variantides ( $\mathrm{kg}$ toimeainet hektarile):

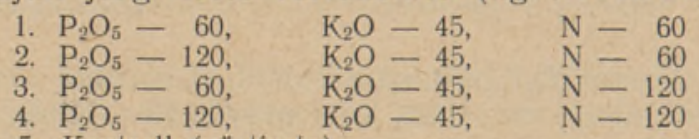

5. Kontroll (väetiseta).

Vegetatsioonikatse rajati sama skeemi järgi; katsenõudesse, mis olid täidetud $4 \mathrm{~kg}$ mullaga, anti mineraalväetisi: 1,0 või $2,0 \mathrm{~g}$ superfosfaati, $0,4 \mathrm{~g}$ kaalisoola ja 0,6 või $1,2 \mathrm{~g}$ ammooniumsulfaati.

Katseks võeti kolm sorti: „Diamant”, „Kauka” ja „Jõgeva 01926”.

Kasvukuhiku diferentseerumist ja pea algme arenemise käiku katse erinevates variantides jälgiti binokulaarse mikroskoobi abil. Vaatlused näitasid, et väetamata foonil toimus nii taimede kasv kui ka pea kujunemine aeglaselt. Esimeses katse variandis oli taimede kasv ja pea algme diferentseerumine väetamata fooniga võrreldes intensiivsem. Kahekordne fosforikogus (teine variant) kiirendas pea kujunemist, kuna lämmastiku ülekaal toitekeskkonnas (kolmas variant) pikendas pea kujunemise perioodi. Tugeval toitmisel fosfori ja lämmastikuga (neljas variant) toimus kasv eriti intensiivselt pea kujunemise suhteliselt kiire tempo juures.

Katse kõigis variantides teostati saagistruktuuri detailne analüüs. Saadud andmetest nähtub, et taimede toitmise parandamine avaldab tugevat positiivset mõju kõigi saagielementide kujunemisele: suureneb taimede kõrgus, pea pikkus, pähikute arv peas, õite ja terade arv pähikus, eriti aga terade kaal.

Saagielementide väljaarenemise intensiivsus erinevates katsevariantides kõigub suurtes piirides, olenevalt väetamisest ja sordi omadustest. „Kauka” ja „Jõgeva 01926” kasutavad suuremaid väetise annuseid paremini kui 
„Diamant”. „Diamandi” pea madalam produktiivsus on tingitud peamiselt väiksemast 1000 tera kaalust.

Saagistruktuuri kujunemise uurimine seoses sortide kasvu- ja arenemisprotsesside jälgimisega erinevates toitumistingimustes võimaldab õigesti mõista ja selgitada taimede toitevajadusi ning välja töötada taimede toitmise ratsionaalset süsteemi.

\section{Toiteelementide andmise aja mõju saagistruktuuri kujunemisele}

Oheks taimede suunava mõjutamise ja väetiste ratsionaalse kasutamise võtteks on täiendav väetamine, s. o. toiteainete andmine vegetatsiooniperioodil taimede kasvu eri faasides ja erinevates arenemisstaadiumides.

Taimedele eri arenemisperioodidel lämmastikväetise täiendava andmise mõju selgitamiseks suvinisusortide „Diamant”, „Kauka” ja „Jõgeva 01926” saagistruktuuri kujunemisele rajati vegetatsioonikatse.

Katse teostati nõudes, mis sisaldasid $4 \mathrm{~kg}$ mulda. Ohes katsevariandis (kontrollvariant) anti väetised $(1,0 \mathrm{~g}$ superfosfaati, $0,4 \mathrm{~g}$ kaalisoola ja $0,6 \mathrm{~g}$ ammooniumsulfaati nõu kohta) enne külvi. Teistes katsevariantides anti lisaks enne külvi antud väetisele pealtväetisena lämmastikku $(0,6 \mathrm{~g}$ ammooniumsulfaati nõu kohta) kas teise lehe faasis, neljanda lehe faasis, kõrdumisel või loomisel.

Lämmastiku täiendavast andmisest tingitud intensiivsem kasv ja pea algme aeglasem arenemine põhjustasid taimede produktiivsuse tõusu. Teise lehe faasis antud lämmastiku mõjul suurenesid kõik saagielemendid. „Diamant” ja „Jõgeva 01926” saavutasid antud variandis pea kõige suurema produktiivsuse. „Kauka” produktiivsus tõusis veel lämmastiku andmisel neljanda lehe faasis ja kõrdumisel.

Tuleb märkida erinevusi pea elementide kujunemises seoses lämmastiku andmise ajaga. Pähikute arv peas suurenes kõikidel sortidel lämmastiku andmisel teise lehe faasis. Hilisematel perioodidel antud lämmastik-pealtväetis ei tõstnud põhiliselt pähikute arvu peas, sest pea algme diferentseerumine pähikuteks oli selleks ajaks lõppemisel või juba lõppenud. Pähikute moodustamisejärgsel perioodil antud lämmastikväetis tõstis kontrollvariandiga võrreldes tunduvalt õite ja terade arvu, samuti ka 1000 tera kaalu.

„Kauka” kõrgem produktiivsus lämmastiku andmisel hilisematel perioodidel võib nähtavasti olla seletatav asjaoluga, et täiendavat väetamist teostati üldiselt kõrgel väetisfoonil, mistõttu taimede kasvu algperioodil ei olnud lisaväetis veel vajalik. See võib olla seotud ka „Kauka” bioloogiliste iseärasustega. Seega vỗib lämmastiku hilisem andmine kindlustada kõrge saagi ainult kõrgel väetisfoonil ja seda peamiselt õitsemise produktiivsuse tõusu arvel.

Teises katses uuriti üksikute toiteainete mốju saagistruktuuri kujunemisele nende andmisel enne külvi ja valgusstaadiumi algul. Katseandmed kinnitavad, et mineraalväetiste andmine vegetatsiooniperioodil ei anna külvieelse väetamisega võrreldes paremaid tulemusi, kui taimedel ei ole nende arenemise varasel perioodil vajalikul hulgal toiteaineid. Väetiste andmisel ainult vegetatsiooniperioodil jääb saak väiksemaks kui külvieelsel andmisel.

Kui arvestada seda, et taimede nõudmine toiteainete suhtes on kõige suurem valgusestaadiumis, on selge, miks hilisema väetiste andmisega saadakse väiksem efekt. Praktikas tuleb seda arvestada ja mitte hilineda kevadel väetiste andmisega. 
Saagielementide kujunemine olenevalt veerežiimist taimede arenemise eri perioodidel

Veerežiimi mõju suvinisu saagielementide kujunemisele uuriti vegetatsioonikatsetes.

Katsevariandid:

I - veepuudus pärast teise lehe ilmumist

II - veepuudus pärast neljanda lehe ilmumist

III - veepuudus kõrdumisel

IV - veepuudus loomisel

$\mathrm{V}$ - küllaldane mullaniiskus kogu vegetatsiooniperioodil (kontroll).

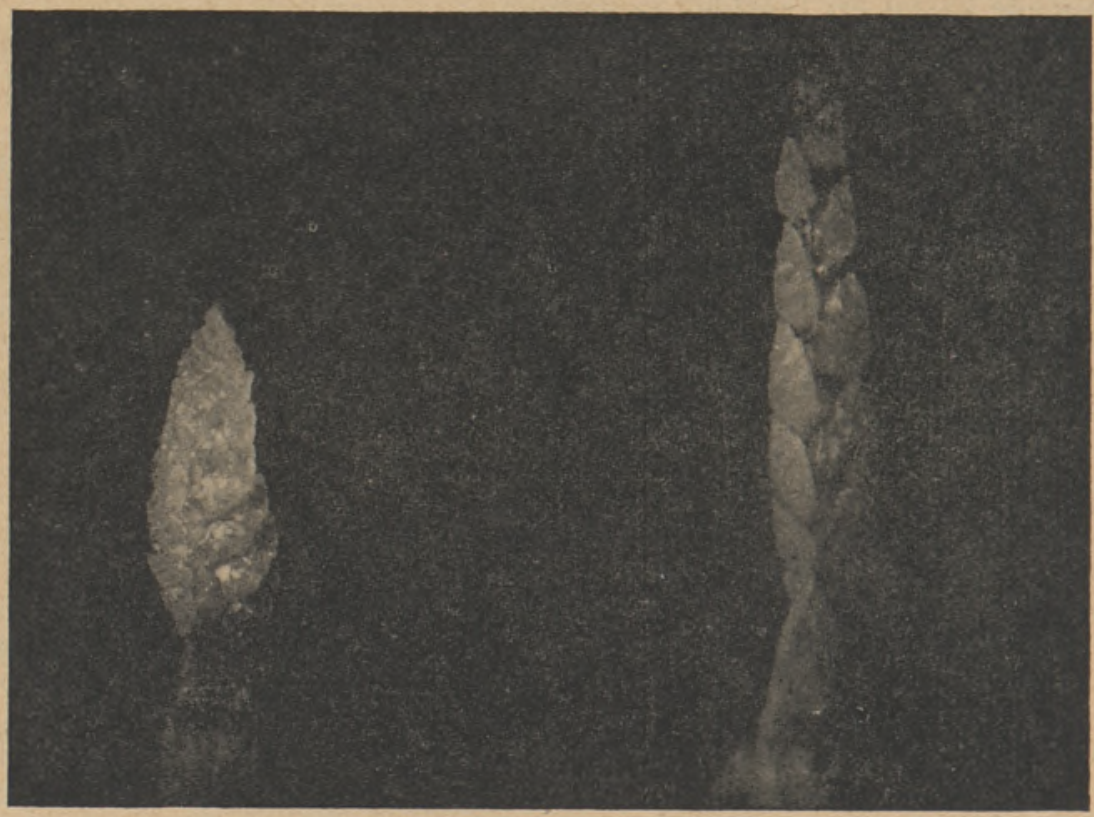

Joon. 4. „Diamandi” pea algme seisund 36. päeval pärast tärkamist. Vasakul kasvanud optimaalse veerežiimi tingimustes. Paremal - kasvanud põuatingimustes (veepuudus teise kuni neljanda lehe faasis, s. o. 11,-23. päeval pärast tärkamist). Pea kujunemine on toimunud kiiremini, kasv on jäänud maha arenemisest, mille tôttu pähikute arv peas on väiksem.

Veepuudus mullas loodi kastmise katkestamisega 12 päevaks. Enne ja pärast ,põuaperioodi" hoiti katsealused taimed samades veerežiimi tingimustes nagu kontrolltaimed. Katse teostati niiskusenõudliku sordiga „Diamant”.

Saagistruktuuri analüüsi andmed näitavad, et pähikute arv pea kohta langeb kõige rohkem veepuudusel pärast teise lehe ilmumist, millal algab pähikute moodustumine (joon. 4). Põud pärast neljanda lehe ilmumist, kui pähikute algmed on juba põhiliselt kujunenud, avaldab negatiivset mõju õite ja terade kujunemisele. Põuatingimused järgnevates arenemisfaasides põhjustavad terade arvu ja 1000 tera kaalu tunduvat langemist.

Saadud andmed kinnitavad, et saagielementide väljaarenemise intensiivsus on otseses seoses veerežiimi tingimustega nende arenemise perioodidel. Põuatingimused avaldavad kõige suuremat pidurdavat mõju selle saagielemendi väljaarendamisele, mille kujunemise perioodil taimi põuaga mõjutatakse. 


\section{Päeva pikkuse mõju suvinisusortide arenemisele ja pea algme kujunemisele}

On teada, et sordid reageerivad päeva pikkuse muutumisele erinevalt. Et selgitada „Diamandi”, „Kauka” ja „Jõgeva 01926” reageerimist päeva pikkusele, rajati katsed põllutingimustes väikestel lappidel. Katsevariandid:

I - loomulik päeva pikkus (kontroll)

II - päeva pikkus 14 tundi

III - päeva pikkus 12 tundi.

Kontrollvariandi taimede valgusestaadiumi läbimine toimus juuni esimesel poolel ca 18-tunnise päeva pikkuse tingimustes. Valgustuse kestust II ja III katsevariandis reguleeriti taimede katmisega tõrvapapiga ülelöödud vineerkastidega:

Katses uuriti pea algme arenemist ja kasvu dünaamikat olenevalt päeva pikkusest.

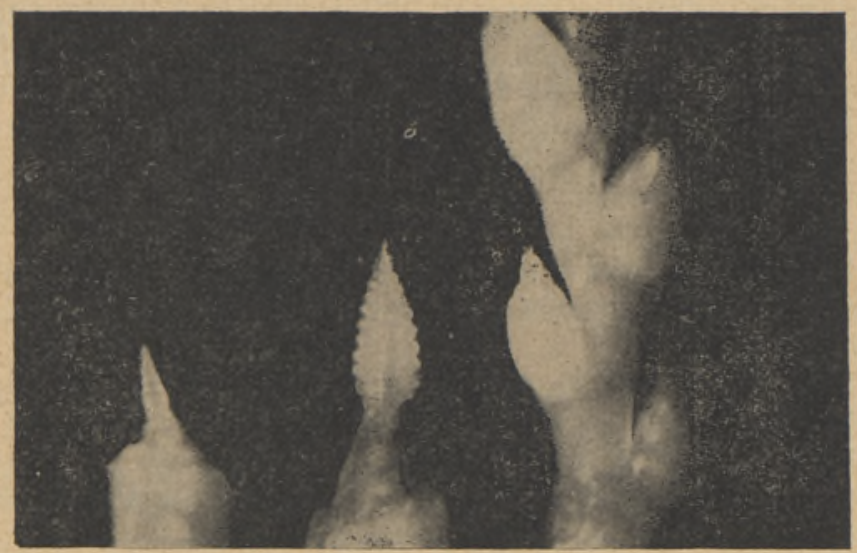

Joon. 5. „Diamandi” pea 43. päeval pärast tärkamist: vasakul 12-tunnise, keskel 14-tunnise päeva pikkuse tingimustes ja paremal loomuliku päeva pikkuse juures.

Taimede kasvu ja arenemise algperioodil - esimesel kahel nädalal pärast tärkamist - ei esinenud katsevariantide piires märgatavaid erinevusi kasvukuhiku arenemises. Viieteistkümnendal päeval pärast tärkamist võis juba kõikide sortide juures märgata erinevusi kasvukuhiku diferentseerumises olenevalt päeva pikkusest. Loomuliku päeva pikkuse tingimustes oli kasvukuhiku väljaulatumine ja diferentseerumine mõnevõrra intensiivsem lühendatud päeva, eriti 12-tunnise päeva tingimustega võrreldes.

Edasises arenemises ilmnesid sortide piires olulised erinevused. „Diamandi" pea algme arenemine oli lühikese päeva tingimustes rohkem pidurdatud kui „Kaukal” ja „Jõgeva 01926-1”.

Teiste sortidega võrreldes reageeris lühikese päeva tingimustele kõige rohkem „Diamant”. „Diamandi” loomine algas 14-tunnise päeva pikkuse puhul 29 päeva võrra hiljem kui loomuliku päeva tingimustes (joon. 5). „Kauka” loomine hilines 21 päeva ja „Jõgeva 01926” oma 19 päeva võrra.

Suhteliselt aeglasem arenemine lühema päeva tingimustes soodustas pea elementide kujunemist. 14-tunnise päeva pikkuse juures omasid taimed keskmiselt 3-5 pähikut pea kohta rohkem kui loomuliku päeva puhul. 12-tunnise päeva pikkuse puhul kestis pähikute diferentseerumise periood veel kauem ning pähikute arv peas suurenes, kuid taimed ei loonud kuni hilissügiseni. 
Taimede kasvu ja arenemise tempo reguleerimine võimaldab tõsta pea produktiivsust ning suurendada pähikute ja terade arvu peas. Päeva pikkuse mõju saagistruktuuri kujunemisele vajab üksikasjalisemat uurimist seoses erinevate külviaegade ja teiste agrotehniliste vootete rakendamisega. See uurimine võib anda väärtuslikke juhiseid nii agrotehnikale kui ka sordiaretusele.

\section{Järeldused}

1. Võitluses suurte nisusaakide eest on Eesti NSV-s kasutada palju reserve. Saagi kujunemise uurimine akad. T. D. Lõssenko poolt välja töötatud taimede stadiaalse arenemise teooria alusel näitab meile kätte tee taimede produktiivsuse tõstmiseks ja suurte saakide saamiseks kasvu ning arenemisprotsesside teadliku suunamise teel. Teostatud uurimised suvinisu saagi kujunemise alal Eesti NSV-s näitavad, et saagistruktuuri elementide arenemine toimub erinevates väliskeskkonna tingimustes väga erinevalt. Olulist osa etendavad ka sortide bioloogilised omadused.

2. Paljude saagi suurusí määravate tegurite hulgas on tähtsaim väeıamise intensiivsus. Kõrgemal agrofoonil, hea toite- ja veerežiimi tingimustes tõuseb suvinisu saak järsult kõigi saagielementide suurenemise tulemusena. Suureneb produktiivsete kõrte arv pinnaühikul, kasvab pähikute arv peas, terade arv pähikus ja 1000 tera kaal. Produktiivsete kõrte arvu suurenemine pinnaühikul on tingitud suuremast tärkavusest kõrgemal foonil, taimede väiksemast väljalangemisest vegetatsiooniperioodi kestel ja taimede rohkemast võrsumisest.

3. Tähtis on toiteainete õigeaegne andmine. Katsed näitasid, et taimed vajavad kōiki toiteaineid juba varasel arenemisperioodil. Kui enne külvi väetisi ei antud, vaid neid anti alles valgusestaadiumi algul (pärast teise lehe ilmumist), siis vähenes pähikute ja terade arv peas, langes 1000 tera kaal ja kogusaak.

Lämmastiku kasutamine pealtväetisena osutus kõige efektiivsemaks selle andmisel valgusestaadiumi algul, kuid lämmastiku hilisem täiendav andmine võib kõrgel väetisfoonil kindlustada saagi edasise tõusu õitsemise produktiivsuse ja terade arvu suurenemise tulemusena.

4. Heades kasvutingimustes ületavad Jõgeva Riiklikus Sordiaretusjaamas aretatud perspektiivsed suvinisusordid Eesti NSV-s rajoonitud sorti „Diamant”. Jõgeva sortide saagistruktuuri iseloomustab ,Diamandiga” võrreldes suurem produktiivsete kõrte arv pinnaühiku kohta ja pea suurem produktiivsus. Madala mullaviljakuse tingimustes nende sortide enamsaak väheneb.

Parimaid tulemusi andis „Jōgeva 01926”, mille terasaak oli 1951. aastal 45,4 ts/ha. Ta omab suurt tera, palju teri peas ja annab tiheda kõrteseisu pinnaühiku kohta.

5. Eesti NSV tingimustes omab saagielementide kujundamisel ja seega saakide tõstmisel erilist tähtsust külviaeg. Varase külvi korral tõuseb suvinisu saak tunduvalt. See on seletatav sellega, et varase külvi korral satuvad taimede kasv ja arenemine ning valgusestaadiumi läbimine niisugustesse tingimustesse, mis kindlustavad nii kôrte kasvutiheduse kui ka pea produktiivsuse tõusu hilisemate külvidega võrreldes.

6. Taimede seisutiheduse reguleerimine külvinormi muutmisega avaldab saagile suurt mõju. Külvinormi suurendamisega saak esialgu tõuseb, kuid edasisel külvinormi suurendamisel hakkab uuesti langema pea produktiivsuse tunduva vähenemise tõttu. Sordid reageerivad külvinormi suurendamisele erinevalt. Seepärast on vajalik iga sordi jaoks välja selgitada optimaalne külvinorm, mis võimaldab tootmistingimustes erinevatel agrofooni- 
del maksimaalsete saakide kasvatamist. Oige külvinormi kasutamine on üks tähtsamaid saagikuse tõstmise reserve.

7. Uks olulisi tegureid, millest oleneb saagielementide kujunemine, on päeva pikkus. Lühendatud päeva tingimustes aeglustub nisutaimede arenemine ning suureneb pähikute arv peas võrreldes taimedega loomuliku valgustuse tingimustes. Olenevalt sortide bioloogiliste omaduste erinevustest, avaldab päeva pikkus sortidele erisugust mõju. „Diamant” on päeva pikkuse suhtes nõudlikum kui „Kauka” ja „Jõgeva 01926”.

8. Peale kasvutingimuste ja sortide pärilike omaduste avaldab saagi kujunemisele suurt mõju ka taimede elujõulisuse aste. Sortidevahelisest ristamisest vaba tuultolmlemise teel saadud hübriidid on emasortidega võrreldes elujōulisemad ja omavad väärtuslikumaid majanduslikke tunnuseid. „Diamandi” ja „Kauka” hübriidseemne saagistruktuuri iseloomustas emasortide saagistruktuuriga võrreldes paremast tärkavusest tingitud suurem taimede seisutihedus, suurem terade arv peas ja suurem 1000 tera kaal.

9. Suvinisusaakide tõstmise reservide igakülgseks ärakasutamiseks on vajalik jätkata uurimisi saagikuse tõstmise bioloogiliste aluste selgitamiseks ning nende uurimiste alusel täiendada suurte saakide kasvatamise agrotehnikat vastavalt ühe või teise sordi bioloogilistele iseärasustele. Arvestades sortide bioloogilisi erinevusi, peab suurte saakide agrotehnikat täiendama sordiagrotehnikaga.

Eesti NSV Teaduste Akadeemia

Taimekasvatuse Instituut

Saabus toimetusse 12. III 1954

\section{KIRJANDUS}

1. G. M a lenkov, Aruandekõne UK(b)P Keskkomitee tööst Partei XIX kongressile, Tallinn, 1952, lk. 45.

2. T. D. L. õ s s e n k o, Agrobioloogia, Tartu, 1949, lk. 39.

3. С. Д. Г реб ен н и ко в, Анализ урожая и элементов урожайности пшеницы Цезиум 0111, Труды Омского сельскохозяйственного института имени С. М. Кирова, Том III (XVI), Омск, 1938, стр. 99.

4. В. Т. Е рем ен ко, О промежуточном периоде развития и анатомо-морфологических признаках световой стадии у пшеницы, Доклады АН CCCP, т. XVIII, № 8, 1938.

5. Г. В. З а бл уда, О фазах формирования генеративных органов у пшеницы, Доклады АН СССР, т. XXIII, № 4, 1939.

6. Л. С. Л у к я н ов, Динамика формирования колоса яровой пшеницы Мелянопус 069 в связи с прохождением стадий развития, Научные записки Украинского научно-исследовательского института соц. земледелия, т. I, вып. 2. 1940, стр. 90.

7. Н. С. Пет и нов и Г. А. 3 а к, Влияние минеральных удобрений на формирование зачаточного колоса и урожай яровой пшеницы, Доклады ВАСХНИЛ, вып. 8, 1940 , стр. 21.

8. В. Е. П и с а р е в, Селекция на урожайность, Соц. реконструкция сельского хозяйства, № 9-10, 1937.

9. М. С. С а ви ц к и й, Биологические и агротехнические факторы высоких урожаев зерновых культур, Москва, 1948.

10. А, А. С а пегин, Ход развития колоса пшеницы, Доклады АН СССР, т. ХVIII, № 3, 1938.

11. Н. А. У с п е н с к и й, Продуктивность сортов яровой пшеницы и метод подбора их для скрещивания по интенсивности прохождения отдельных периодов развития, Записки Воронежского сельскохозяйственного института, т. XXI, вып. I, Воронеж, 1947.

12. А. К. Фед оров, К вопросу о дифференциации конуса нарастания в связи со стадийным развитием растеннй, «Агробиология», № 1, 1953. 


\title{
СТРУКТУРА УРОЖАЯ ЯРОВОИ ПШЕНИЦЫ В ЗАВИСИМОСТИ ОТ БИОЛОГИЧЕСКИХ ОСОБЕННОСТЕЙ СОРТОВ И УСЛОВИЙ ВЫРАЩИВАНИЯ
}

\author{
о. Я. приилинн, \\ кандидат сельскохозяйственных наук
}

Резюме

Успешное выполнение поставленных партией и правительством задач по повышению урожайности сельскохозяйственных культур, в частности по увеличению производства пшеницы, требует знания биологических основ управления урожаем.

Задачей наших исследований было на основе изучения биологических особенностей сортов яровой пшеницы научно обосновать пути разработки сортовой агротехники для дальнейшего повышения урожайности этой культуры в Эстонской ССР: В опытах было изучено формирование элементов урожая сортов яровой пшеницы в различных условиях роста и развития на основе теории стадийного развития растений.

Исследования показывают, что в борьбе за высокие урожаи в нашем распоряжении имеются большие резервы. Разработанная акад. Т. Д. Лысенко теория стадийного развития растений указывает на возможность повышения продуктивности растений путем сознательного направления процессов роста и развития.

Формирование определяющих урожай элементов - число продуктивных стеблей на единицу площади, число колосков в колосе, число зерен в колоске и вес 1000 зерен - при разных внешних условиях происходит весьма различно. Существенное значение при этом имеют биологические особенности сортов.

Сравнительное изучение сортов на различных фонах показало, что на высоком агрофоне при хорошей обеспеченности питательными веществами и достаточной влажности почвы урожаи яровой пшеницы резко повышаются благодаря хорошему развитию всех элементов урожая. Возрастание числа продуктивных стеблей при этом обусловливается более высокой полевой всхожестью, уменьшением выпадения растений в вегетационном периоде и более интенсивным кущением.

Для получения высокого урожая очень важным является своевременное внесение питательных веществ. Опыты показали, что опоздание с внесением в почву питательных веществ обусловливает ухудшение структуры урожая и уменьшение его. Если фосфорное, калийное и отчасти азотное удобрения перед посевом не были внесены, а вносились по всходам в фазе второго листа, то это приводило к снижению числа колосков и зерен в колосе и к уменьшению веса 1000 зерен по сравнению с теми вариантами опытов, в которых удобрения были внесены до посева.

Применение азота в подкормках оказалось наиболее эффективным в начале прохождения световой стадии. Более поздние подкормки азотом могут обеспечить дальнейшее повышение урожая за счет лучшего завязывания семян при цветении и увеличения вследствие этого числа зерен в колосках, но это повышение имеет место лишь в том случае, если растения получили обильное питание в самом раннем периоде жизни.

Сорта Иыгеваской государственной селекционной станции, выведенные на высоком агрофоне, при обильном удобрении значительно превосходят по урожайности районированный в Эстонской ССР сорт Диамант, благодаря тому, что они в этих условиях образуют большее число продуктивных стеблей на единицу площади и более продуктивный колос, чем 
Диамант. В условиях низкого плодородия почвы различия в урожайности их, по сравнению с урожаем сорта Диамант, уменьшаются. Наиболее урожайным является перспективный сорт яровой пшеницы Иыгева 01926 , урожай которого в 1951 году в опытах составил 45,4 ц с га. Иыгева 01926 имеет крупное зерно, много зерен в колосе и отличается густым стеблестоем (табл. 1).

Проведенными ранее в Институте растениеводства Академии наук Эстонской ССР исследованиями (Э. Халлер) доказано, что одним из важнейших условий для получения высоких урожаев яровой пшеницы в Эстонской ССР является правильный выбор срока посева. При раннем посеве урожай значительно повышается. Наши исследования показывают, что различия в условиях, которые создаются разными сроками посева, вызывают существенные различия в росте, процессах развития и формировании элементов урожая. При раннем посеве прохождение стадии яровизации и световой стадии, в сравнении с поздними сроками посева, совпадает с более благоприятными условиями для получения густого стеблестоя и формирования продуктивного колоса: развитие и рост проходят при более низкой температуре, более благоприятных водном режиме и длине дня. С запозданием посева, вследствие пересыхания верхних слоев почвы значительно понижались полевая всхожесть семян и кущение растений. Одновременно увеличивалось число непродуктивных стеблей на единицу площади. При позднем посеве урожай зерна у сорта Иыгева 01926 понизился больше, чем у сортов Диамант и Каука.

В зависимости от агробиологических особенностей сортов и от условий выращивания необходимо для обеспечения высоких урожаев вместе с другими агротехническими приемами дифференцировать и нормы высева. Исследования показывают, что соответствующая каждому сорту оптимальная норма высева обеспечивает более полное использование особенностей сорта для повышения урожайности и является одним из важных звеньев в комплексе сортовой агротехники.

При увеличении густоты стеблестоя до известного оптимума урожай зерна с единицы площади повышается, несмотря на одновременное понижение продуктивности колоса.

Чрезмерное увеличение нормы высева приводит к уменьшению урожая вследствие значительного снижения продуктивности колоса. Продуктивность колоса Каука по сравнению с Диамантом и Иыгева 01926 при увеличении посевной нормы (до 800 всхожих семян на 1 кв. м) понизилась меньше. Результаты наших опытов и производственный опыт указывают на необходимость выяснить резервы повышения урожайности отдельных сортов путем увеличения нормы высева, в частности сорта Каука.

В вегетационных опытах было изучено формирование элементов урожая в зависимости от водного режима в отдельные периоды развития растений. Исследования подтвердили тот факт, что условия засухи оказывают наибольшее влияние на тот элемент урожая, в период формирования которого засуха оказывает воздействие на растение. При недостатке воды после появления второго листа, когда начинается образование колосков, сильнее снизилось число колосков в колосе. Засуха после появления четвертого листа, когда зачатки колосков уже в значительной степени сформировались, оказала отрицательное влияние на формирование цветков и зерен. Засуха в последующих периодах развития оказала значительное влияние на снижение числа зерен в колосе и веса 1000 зерен.

Различие биологических особенностей сортов проявляется и в различном их отношении к длине дня. Длина дня является важным фактором, от которого также зависит формирование элементов урожая. При прохождении световой стадии в условиях 14-часового дня развитие проте- 
кало медленно и увеличивалось число колосков в колосе по сравнению с вариантом в условиях естественного дня. Диамант сильнее реагировал на сокращение длины дня, чем Каука и Йгева 01926. Колошение у Диаманта при 14-часовом дне наступило на 29 дней позднее, чем в условиях естественного дня. Колошение у Каука при 14-часовом дне запоздало на 21 день, а у Йыгева 01926 на 19 дней. В условиях 12-часового дня период дифференциации колосков растянулся еще больше и число колосков в колосе еще повысилось, но при этом растения всех сортов не выколосились до поздней осени.

Кроме внешних условий и биологических особенностей сортов, на урожайность оказывает большое влияние степень жизненности растений. Полученные при свободном межсортовом переопылении гибриды сортов Диамант и Каука обладали более высокой жизненностью по сравнению с материнскими сортами. В результате повышенной жизненности эти гибриды имели более высокую полевую всхожесть, обеспечивающую более густое стояние растений, а также отличались бо́льшим числом зерен в колосе и бо́льшим весом 1000 зерен по сравнению с материнскими сортами. Это преимущество межсортовых гибридов по урожайности в большей степени проявляется на высоком агрофоне.

Для всестороннего использования резервов повышения урожайности яровой пшеницы необходимо продолжать углубленное изучение биологических особенностей сортов и, исходя из этих особенностей, применительно к каждому сорту разработать агротехнику высоких урожаев.

Ннститут растениеводства Академии наук Эстонской ССР
Поступила в редакцию 12 III 1954 